\title{
Red Data Updates for Orenburg Oblast
}

\section{O G Kalmykova, N O Kin, and P V Velmovsky}

Department of Landscape Ecology, Institute of Steppe, Ural Branch RAS, Orenburg, Russia

\section{Abstract}

One of the ways to study and protect flora is keeping and publishing regional Red Data Books. A floristic study resulted in a series of data on the flora of Orenburg Oblast, which made it possible to make a set of criteria for updating the list of regional species for conservation. In early 2018, the authors proposed 6 species of vascular plants to be registered in the Red Data Book of Orenburg Oblast including Stipa zalesskii Wilensky, Iris aphylla L., Botrychium lunaria (L.) Sw., Pedicularis palustris L., Saxifraga sibirica L., Salvia glutinosa L. The registration of some of them in the Red Data Book was recommended in view of an increased anthropogenic adverse impact on their habitats and a growing threat of extinction. On September 2018, the proposed Red Data updates for Orenburg Oblast outlined in this article were adopted and approved by the Government of the Orenburg Oblast.

Corresponding Author: O G Kalmykova okstepposa@gmail.com

Received: 25 October 2019 Accepted: 15 November 2019 Published: 25 November 2019 Publishing services provided by Knowledge E

(c) O G Kalmykova et al. This article is distributed under the terms of the

Attribution License, which permits unrestricted use and redistribution provided that the original author and source are credited.

Selection and Peer-review under the responsibility of the AgroSMART 2019 Conference Committee.

\section{G OPEN ACCESS}

Keywords: Red Data Book, Orenburg Oblast, endangered plants, phytodiversity

\section{Introduction}

Constant research into the state and growth of rare, decreasing and endangered species is crucial in creating floristic conservation guidelines for any area [1--4].

One of the ways to study and protect flora is keeping and publishing regional Red Books. They shall be updated every 10 years, which is not always respected.

The first Red Book of Orenburg Oblast was released in 1998 and evaluated 44 species of vascular plants. Almost all of them (except for 6 species) were registered in the Red Book of the RSFSR (1988). The Appendix also provided a list of 101 most vulnerable plant species in need of special monitoring in the natural environment within the region. In fact, of 44 species in the Red Book, 12 did not grow within the territory of Orenburg Oblast, were uncertain and whose presence in the region was not confirmed [5].

The next update of the list of rare species occurred only in 2012 as per the Decree of the Government of Orenburg Oblast of January 26, 2012 No. 67-p "On the Red Book of Orenburg Oblast". The Plants title included 148 species of angiosperms, 2 species of gymnosperms, 16 species of ferns, 1 species of lycopsids, 10 species of bryophytes. 
However, no explanations for the species listed, as well as the Red Book itself, were published. In 2014, the Resolution of the Government of Orenburg Oblast (dated April 16, 2014 No. 229-p) "On Amendments to the Government Decree (dated January 26, 2012 No. 67-p) "On the Red Book of Orenburg Oblast" was issued to add 9 species of vascular plants to the list of 2012 and exclude the same 9 from the list. Data on rare plant species were published on the website of the Ministry of Natural Resources of Orenburg Oblast only in 2018.

A floristic study resulted in a series of new data on the flora of Orenburg Oblast, which made it possible to make a set of criteria for updating the list of regional species for conservation. In early 2018, the authors proposed 6 species of vascular plants to be registered in the Red Data Book of Orenburg Oblast including Stipa zalesskii Wilensky, Iris aphylla L., Botrychium Iunaria (L.) Sw., Pedicularis palustris L., Saxifraga sibirica L., Salvia glutinosa L. The registration of some of them in the Red Data Book was recommended in view of an increased anthropogenic adverse impact on their habitats and a growing threat of extinction.

\section{Methods and Materials}

Data on rare plant species that exist within Orenburg Oblast was collected during a long-term floristic study. A number of habitats of such species were identified during a survey of differently rated special areas of conservation (Buzuluksky Bor National Park, Orenburg and Shaytan-Tau Nature Reserves known as regional natural sanctuaries). Typical floristic-based methods were used to collect the research material (field and paper).

Compiling the features of particular species implied a review of relevant literature, mainly large floristic reports [6--12] and recent findings of regional flora revision [13, 14]. The contents of Red Books of cross-border regions were analyzed, namely: the Republic of Bashkortostan [15], Tatarstan [16], Samara [18], Saratov [19], Chelyabinsk [20] Oblasts, as well as the current Red Book of the Russian Federation [17]. The study considered not only the presence of a species in the list of taxa for neighboring regions, but its status, as well. The distribution in the region was described using materials from the leading Russian herbarium collections, namely: the LE herbarium of V.L. Komarov Botanical Institute RAS, the MW herbarium of Lomonosov Moscow State University, as well as some regional herbaria including the ORIS herbarium of Institute of Steppe, Ural Branch RAS, the PVB herbarium of the Institute of Ecology of Volga Region RAS, etc. 
The statuses were proposed in accordance with the scale of categories for assessing the status of plant species and fungi listed in Russian Red Data Book [17].

\section{Results}

Stipa zalesskii Wilensky is recommended for inclusion in the regional Red Book as indexed 2, meaning a taxon decreasing as a result of changes in the environment or destruction of habitats.

This species was listed among the plant species for conservation as per the Decree of the Government of Orenburg Oblast (of January 26, 2012 No. 67-p) "On the Red Book of Orenburg Oblast", but was excluded in 2014 by the Decree of the Government of Orenburg Oblast (of April 16, 2014 N 229-p) "On Amendments to the Government Decree (dated January 26, 2012 No. 67-p) "On the Red Book of Orenburg Oblast". The authors believe that the species was unreasonably excluded and should be re-entered in the Red Book of Orenburg Oblast, as it is in the Red Book of the Russian Federation and whose presence has been confirmed in the region. In the Red Book of the Russian Federation, it is indexed 3 , meaning a rare taxon distributed over an extensive territory, but inhabiting a limited territory (the northern border of the habitat extends over some regions in Russia) [17]; it appears in the Red Books of the Republic of Bashkortostan (category 3 -- a rare species) [15] and Tatarstan (category 1 -- an endangered species) [16], Samara Oblast (category 3 -- a rare species) [18], Saratov Oblast (category 2 -- a decreasing species) [19], Chelyabinsk Oblast (category 3 -- a rare species) [20].

East European-West Asian shrub-steppe species is distributed over an extensive territory in the steppe, and partly in the forest-shrub-steppe zone of the European part of the Russian Federation, particularly, within the Stavropol highlands, in the upper part of the $\mathrm{Ob}$ and Yenisei, in the lower and middle zones of the Altai and Western Sayan Mountains. Outside Russia it is also met in Kazakhstan, Ukraine, Moldova, Romania, Slovakia and Mongolia [11, 17]. In Orenburg Oblast, it is found throughout all administrative divisions (LE; ORIS; [14]).

It exists in various ecological types of plain steppes, mountain steppes, swales and sporadically fallow land. In the forest-shrub-steppe zone it is found within shrub-steppe ecosystems, preserved mainly on the slopes, in the northern subzone of the shrubsteppe zone -- in different types of habitats, in the middle -- in damp habitats. In phytocenoses it is usually a dominant or codominant.

In Orenburg Oblast, one of the common types of stipa gigantea, (Fig. 1) is numerous in the surviving shrub-steppe areas. The number is decreasing due to the destruction 
of habitats caused by land cultivation and development. The major environmental resistance includes ploughing and depletion (including in oil and gas production, construction of roads, quarry operations, etc.) of virgin grassland cover and old-age arable soil, excessive cattle grazing and recreational landscape impact.

It is protected in Orenburg and Shaytan-Tau state Nature Reserves, as well as in the territory of some regional natural sanctuaries (Mount Verblyuzhka, Kuvaiskaya Steppe, Karagai Bor, etc.)

To preserve the species from extinction, ploughing virgin steppes and old-age arable soil with Stipa zalesskii to grow should be banned as well as moving across the shrubsteppe areas off the permissible beaten paths. Monitoring the status of populations and possible cultivation in botanical gardens are recommended $[15,17]$.

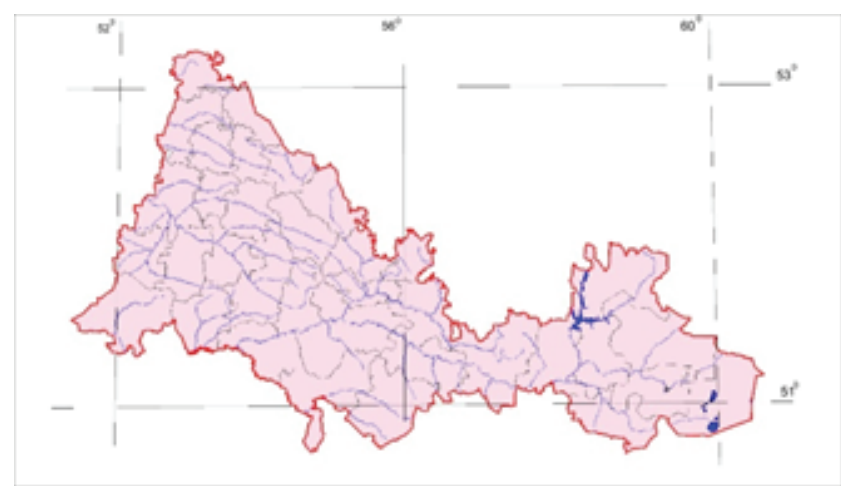

Figure 1: Stipa zalesskii distribution in Orenburg Oblast. Thereafter, the administrative divisions of Orenburg Oblast are marked pink.

Iris aphylla L. (incl. Iris hungarica Waldst. \& Kit., Iris aphylla L. spp. Hungarica (Waldst. $\&$ Kit.) Hegi) -- recommended for protection as indexed 1, meaning endangered species in Orenburg Oblast along the eastern border of the habitat. It is listed in the Red Book of the Russian Federation (category 2 -- a decreasing species, i.e. a taxon whose number is being reduced as a result of changes in the environment or destruction of habitats) [17]; listed in the Red Books of the Republic of Tatarstan (category 2 -- a decreasing species located along the northeastern border of the habitat) [16], Samara Oblast (category 3 -a rare species) [18] and Saratov Oblast (category 2 -- a vulnerable species) [19 ].

The habitat of the species straddles Central and Eastern Europe, the Mediterranean (Balkans), Asia Minor, the Caucasus [9, 17]. In Russia, it is found mainly in the chernozem zone of the European part [17], including Transvolga region [9]. It grows in light pine and pine-deciduous forests, on the outskirts of the wood and forest glades [9, 18]. In Orenburg Oblast it is found only in the Buzuluk Pine Forest. More than 100 years ago (in 1916) it was collected by L. Gursky within the present borders of the Buzuluk park but there is still no evidence to confirm the habitat. Today, the presence of this species has 
been reliably confirmed only in the protected area of the national park inside the forest (Fig. 2), in the area nearby subsoil use sites (ORIS). The major environmental resistance includes habitat destruction due to economic activity (including oil production, logging, etc.).

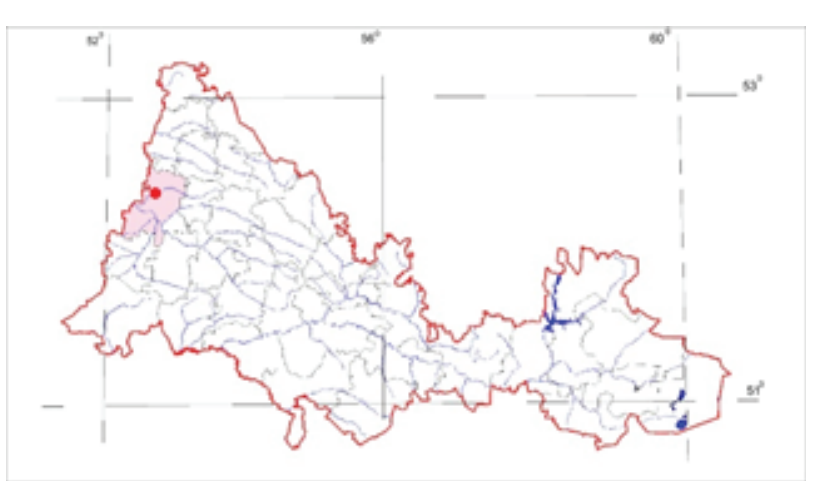

Figure 2: Iris aphylla distribution in Orenburg Oblast.

Today, the only habitat of the species is known to be a restricted area inside the Buzuluksky Bor National Park protected. It is necessary to monitor the status of the population through the identification of new habitats of a taxon for conservation; prohibition of economic activities in the habitats; organization of fire precaution; elimination of the likelihood of any changes in the hydrological regime within the area.

Botrychium lunaria (L.) Sw. is proposed for conservation as a species indexed 4 meaning uncertain status. It is registered in the Red Book of the Republic of Bashkortostan (category 2 -- a vulnerable species) [15] and Tatarstan (category 2 -- a vulnerable species) [16], Samara Oblast (category 1 -- an endangered species) [18], Saratov Oblast (category 3 -- a rare species) [19] and Chelyabinsk Oblast (category 3 -- a rare species) [20].

The habitat encompasses Europe, the Caucasus, Western and Eastern Siberia, the Far East, Central Asia, the Himalayas, North and South America and Australia [7, 12]. The species is provided for the eastern regions of the European part of Russia [7, 12], including Transvolga region [7]. In Orenburg Oblast, it is supposed to grow on smallgrass upland meadows, on the outskirts of the wood, rocky, sodded slopes, very rarely, in the northern regions [14]. The only current reliably confirmed habitats in Orenburg Oblast are located in the protected zone of the Buzuluksky Bor national park inside the forest, in the area nearby subsoil use sites (ORIS). In currently known habitats in Orenburg Oblast, it grows in deciduous damp shady forests. There are three reliably confirmed habitats, all in the Buzuluksky Bor, sporadically in two of them, and in groups of up to 25 specimens in the third habitat. The major environmental resistance includes habitat destruction due to economic activity (including oil production, logging, etc.). 
The currently confirmed habitats of the species are located in a restricted area of the Buzuluksky Bor national park (Fig. 3).

It is necessary to monitor the status of the population through the identification of new habitats of a taxon for conservation; prohibition of economic activities in the habitats; organization of fire precaution; elimination of the likelihood of any changes in the hydrological regime within the area.

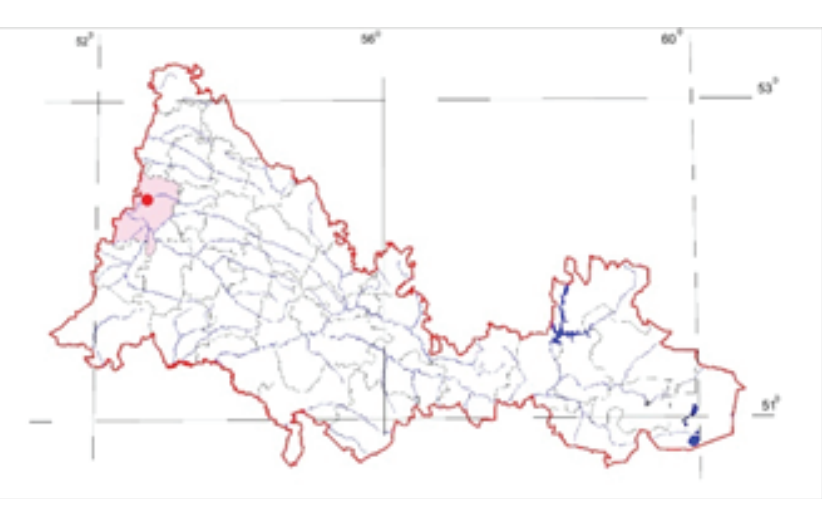

Figure 3: Botrychium lunaria distribution in Orenburg Oblast.

Pedicularis palustris $L$. was proposed for conservation as a species indexed 3 meaning a rare species inhabiting a limited territory or sporadically distributed over an extensive territory. It is registered in the Red Book of the Republic of Tatarstan (category 2 -- a vulnerable species) [16] and Saratov Oblast (category 1 -- an endangered species) [19].

It spreads out across Europe, the Caucasus (Fore-Caucasus), Western Siberia, and North America [10]. It is provided for Volga region [10, 13]. In Orenburg Oblast, a rare species (Fig.4), is present in the Buzuluksky Bor, on the bank of the Solyanka River in Kvarkensky District (LE, [14]), close to the western border of the Burtinskaya Shrubsteppe sector of the Orenburg Nature Reserve, in Yasnensky District on the bank of the Kumak River (ORIS), and indicated without more precise reference for the western and north-western districts of the region [13]. The herbarium specimens (LE) indicate that in the middle of the $19^{\text {th }}$-- early $20^{\text {th }}$ centuries this species was found on the outskirts of Orsk (1852, Leg. Antonow, Det. E. Wulff), near the village of llyinskaya (1895, D. Litvinov), on the outskirts of Khutor Novocherkassky of Orsk district (1917, V.M. Krasheninnikova), east of the village of Novo-Sakmara (1931, K.S. Afanasyev). It grows along the banks of water bodies, marshy meadows and shrubs and other damp habitats. No abundance data is available. The major environmental resistance includes the destruction and change of environmental conditions of habitats due to economic activity, excessive cattle grazing and recreational impact. 
The taxon is protected on the territory of the Buzuluksky Bor National Park, in the protected area of the Burtinskaya Shrub-steppe of the Orenburg Nature Reserve. It is required to identify new habitats of the species for conservation and restrict economic activities within the habitats or nearby.

Saxifraga sibirica L. -- indexed 3 that implies a low number of individuals inhabiting a limited territory or sporadically distributed over an extensive territory. It is registered in the Red Book of Chelyabinsk Oblast (category 3 -- a rare species) [10].

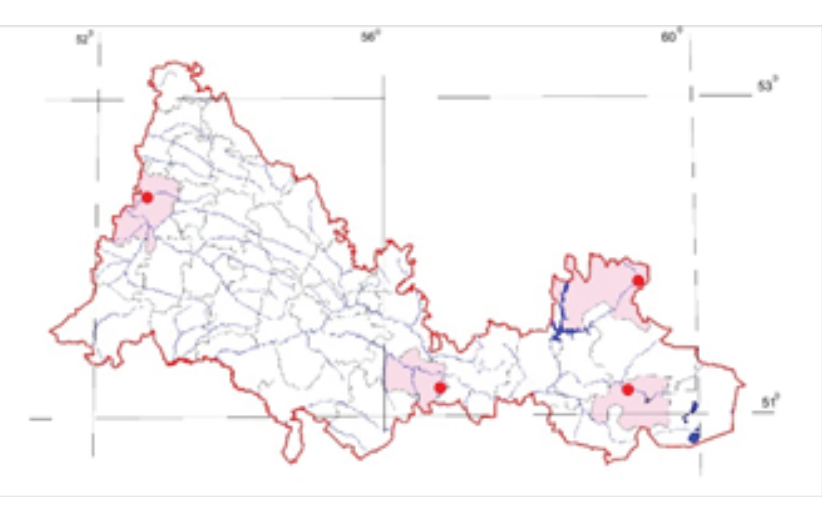

Figure 4: Pedicularis palustris distribution in Orenburg Oblast.

It is found in the Caucasus, Siberia, the Far East, Central Asia, Mongolia, Tibet, Iran, the Mediterranean, Asia Minor, and European Russia. It is provided for Volga region [6]. In Orenburg Oblast, its habitats are known (Fig. 5) on the cliffs along the banks of the Urtazym (ORIS; SVER, [14]) and the Ural (SVER, [21]) in Kvarkensky District, as well as in Kuvandyksky District along the Shaytantau ridge (ORIS, MW). It grows on rocky, gravelly slopes, in rock crevices (mainly on limestones). No abundance data is available. The major environmental resistance includes low ecological adaptability and low competitiveness of the species [20], destruction of habitats, excessive recreational and tourist impact.

It is protected in the territory of the Shaytan-Tau Nature Reserve. Necessary protection measures involve prohibition of tourism and recreation; restriction of economic activities in the habitats; monitoring the status of populations.

Salvia glutinosa $\mathrm{L}$. is recommended for conservation as indexed 4 -- uncertain status, located in Orenburg Oblast near the eastern border of the habitat. It is registered in the Red Book of the Republic of Bashkortostan (category 0 -- probably extinct) [15] and Tatarstan (category 1 -- an endangered species) [16], Samara Oblast (category 2 -a vulnerable species) [18] and Saratov Oblast (category 1 -- a species under threat of extinction) [19]. 


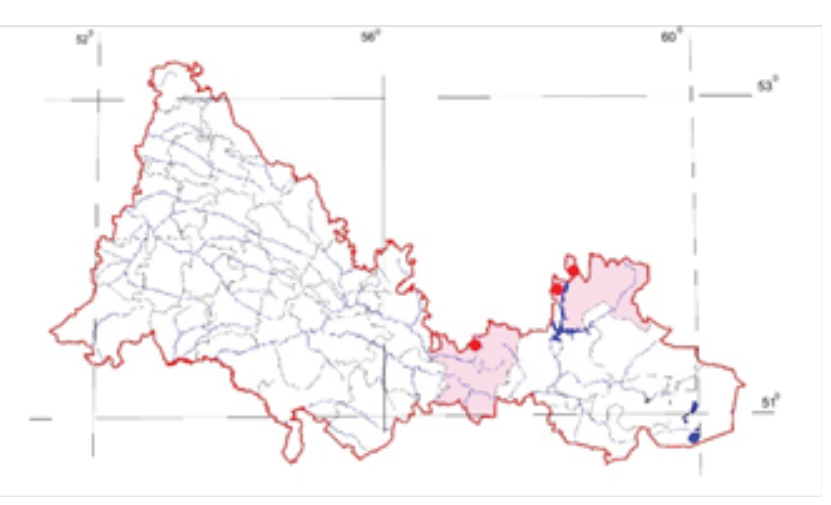

Figure 5: Saxifraga sibirica distribution in Orenburg Oblast.

The habitat straddles South, Middle and Eastern Europe, the Caucasus, and northern Iran [8]. It is provided for Transvolga region [8, 13]. In Orenburg Oblast, the taxon is reliably confirmed only within Buzuluksky Bor National Park (Partisan Forestry) (ORIS). The presence of this species in Buguruslan District is assumed [14]. It grows on the outskirts of sparse deciduous forests. Two habitats are reliably known only in the Buzuluk Pine Forest. The populations are sporadically distributed, rarely by $2--3$ individuals. The major environmental resistance includes excessive recreational and tourist impact, economic activity in habitats (logging, cattle grazing), forest fires, picking up bouquets.

Current habitats are located in the Buzuluksky Bor National Park. It is necessary to monitor the status of the population through the identification of new habitats of a taxon for conservation; prohibition of economic activities in the habitats; organization of fire precaution.

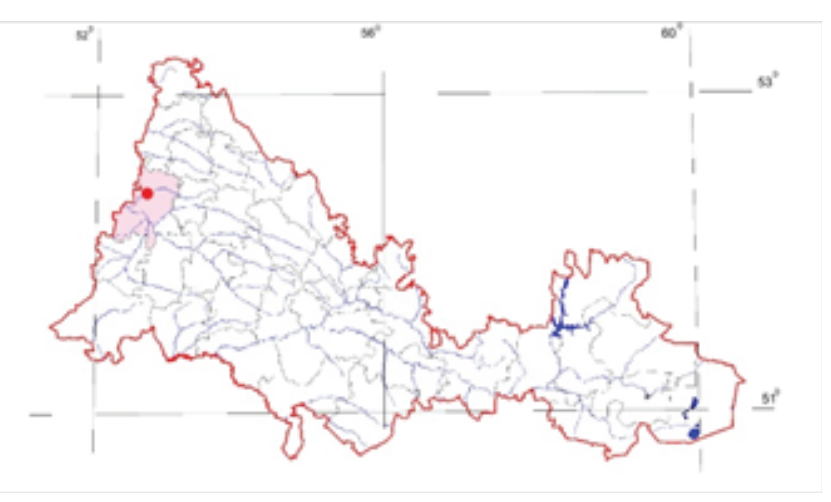

Figure 6: Salvia glutinosa distribution in Orenburg Oblast.

\section{Conclusion}

On September 2018, the above outlined proposals for supplementing the Red Book of Orenburg Oblast were adopted and approved by the Government of Orenburg Oblast. 
This will allow preserving the rarest plant species for the region under the rapidly increasing anthropogenic effect. This problem is particularly urgent for Botrychium Iunaria and Iris aphylla, since their habitats are located in close proximity to the areas of the Buzuluk Park reserved for oil production.

Although Stipa zalesskii Wilensky is widely distributed throughout the territory of Orenburg Oblast, the rate of anthropogenic transformation of the communities it forms is extremely high. The best way to preserve this and other shrub-steppe species for conservation (including Stipa) is a complete, statutory ban on plowing virgin steppes.

Conservation of rare plant species is most effective with an integrated approach, involving the preservation of populations in nature, renewal in botanical gardens, and habitat protection $[22,23]$, including differently rated special areas of conservation $[24,25]$.

\section{Acknowledgment}

The work was carried out under the budget topic of the Institute of Steppe, Ural Branch RAS No.GR AAAA-A17-117012610022-5. Field studies were carried out using the Buzuluksky Bor station of the Institute of Shrub-steppe of the Ural Branch of the Russian Academy of Sciences.

\section{References}

[1] Rodrigues, A.S.L., Brooks, Th.M., Hoffmann, M., Lamoreux, J.F., Pilgrim, J.D. (2006). The value of the IUCN Red List for conservation. Trends in Ecology \& Evolution, vol. 21, iss. 2, pp. 71--76.

[2] Jackson, P.W., Kennedy, K. (2009). The Global Strategy for Plant Conservation: a challenge and opportunity for the international community. Trends in Plant Science, vol. 14 , iss. 11 , pp. $578--580$.

[3] Gjerde, I., Heegaard, E., Grytnes, J.-A., Sætersdal, M., Tingsta, L. (2018). Red List updates and the robustness of sites selected for conservation of red-listed species. Global Ecology and Conservation, vol. 16, pp. 1--11.

[4] Lacher, T.E., Hilton-Taylor, C. (2018). The IUCN Red List: Assessing Extinction Risk in the Anthropocene. Encyclopedia of the Anthropocene, vol. 3, pp. 33--339.

[5] Knyazev, M.S., Kulikov, P.V. (2009). On species of vascular plants for conservation on the territory of Orenburg Oblast (problems of compiling lists of protected species 
in the regional Red Book). Russian scientific conference Rarities of the Volga basin flora, pp. 77--82.

[6] Flora of Eastern Europ, vol. 10. (2001). St. Petersburg: Mir \& Sem'ya Publ., 670 p.

[7] Flora of the European part of the USSR. (1974). vol. 1. Leningrad: Nauka Publ., 404 p.

[8] Flora of the European part of the USSR. (1978). vol. 3. Leningrad: Nauka Publ., 259 p.

[9] Flora of the European part of the USSR. (1979). vol. 4. Leningrad: Nauka Publ., 355 p.

[10] Flora of the European part of the USSR. (1981). vol. 5. Leningrad: Nauka Publ., 380 p.

[11] Tsvelev, N.N. (1976). Cereals of the USSR. Leningrad: Nauka Publ., 788 p.

[12] Shmakov, A.I. (1999). Key to ferns of Russia. Barnaul: Publishing house of Altai University, $108 \mathrm{p}$.

[13] Plaksina, T.I. (2001). Abstract of the flora of the Volga-Ural region. Samara: Samara University, $388 \mathrm{p}$.

[14] Ryabinina, Z.N., Knyazev, M.S. (2009). Key to vascular plants of Orenburg Oblast. Moscow: Tovarishchestvo nauchnykh izdaniy KMK Publ., 758 p.

[15] The Red Book of the Republic of Bashkortostan (2011). 2rd ed., vol. 1: Plants and fungi. Ufa: MediaPrint Publ., 384 p.

[16] The Red Book of the Republic of Tatarstan (animals, plants, fungi). (2016). 3rd ed. Kazan: Idel-Press Publ., 760 p.

[17] The Red Book of the Russian Federation (Plants and fungi). (2008). Moscow: Tovarishchestvo nauchnykh izdaniy KMK Publ., 855 p.

[18] The Red Book of Samara Oblast, vol. 1: Rare species of plants and fungi. Samara: Publishing House of the Samara State Regional Academy (Nayanova), 2017, 284 p.

[19] The Red Book of Saratov Oblast. Mushrooms. Lichens. Plants. Animals. (2006). Saratov: Publishing House of Trade and Industrial Chamber of Saratov Oblast, 528 p.

[20] The Red Book of Chelyabinsk Oblast: animals, plants, fungi. (2017). Moscow: Reart Publ., $450 \mathrm{p}$.

[21] Knyazev, M.S., Yamalov, S.M., Golovanov, Ya.M., Kalmykova, O.G., Tabuldin, Yu.Z. (2017). Floristic evidence in Orenburg Oblast. Bulletin of the Moscow Society of Nature Testers. Department of Biology, vol. 122. no. 3, pp. 66--69. 
[22] Khoury, C.K., Amariles, Dz., Soto, J.S. et el. (2019). Comprehensiveness of conservation of useful wild plants: An operational indicator for biodiversity and sustainable development targets. Ecological Indicators, vol. 98, pp. 420--429.

[23] Murray, B.G. (2017). Plant Diversity, Conservation and Use, Encyclopedia of Applied Plant Sciences, 2rd ed., vol. 2, pp. 289--308.

[24] Orsenigo, S., Montagnani, Ch., Fenu, G., Gargano, D., Rossi, G. (2018). Red Listing plants under full national responsibility: Extinction risk and threats in the vascular flora endemic to Italy. Biological Conservation, vol. 224, pp. 213--222.

[25] Heywood, V.H. (2018). Conserving plants within and beyond protected areas -- still problematic and future uncertain. Plant Diversity, pp. 1-14. 